\title{
The effect of commercial pectolytic enzymes on young Babić wines quality
}

\begin{abstract}
The purpose of this research was to determine the effect of commercial pectolytic enzymes on the anthocyanin composition, colour parameters and specific sensory atributes in young wines produced of Croatian autochthonous variety Babić. The maceration without commercial enzymes was compared with two different enzymes: pectinase with additional cellulase and hemicellulase activity $(A)$ and the pectinase with inactive yeast cells (B), during two harvests. Both products had a positive effect on the anthocyanin content and composition, but with different intensities. The influence of enzymes was confirmed through the colour parameters; intensity, hue and the ratio between yellow, red and blue, depending on product. Young wines produced with pectinase enzyme were significantly better, for all parameters. The sensory analysis showed that wines produced with pectinase enzyme (product A) were significantly better than those produced without enzymes. The combination of pectolytic enzymes and inactive yeast cells (product B) had a partial positive effect on the anthocyanins, colour parameters and sensory quality during two harvests. The use of specific commercial pectolytic enzymes can be a good and beneficial technological treatment in production of Babic young wine, based on preliminary research. These data confirmed the need to carry out research prior to use in real production, to select and recommend certain commercial enzyme products, according to the particular grape variety and certain wine properties that want to be improved.
\end{abstract}

Keywords: anthocyanins, colour, sensory quality, pectolytic enzymes, Babić wine

\section{Introduction}

The use of the commercial pectolytic enzymes in grape maceration is a recognized oenological treatment to enhance extraction of polyphenolic compounds, especially anthocyanins, and improve colour characteristics (Ough and Berg, 1974). The enzymes affect the wine complexity, colour stability and better taste and complexity of wine. Enzyme preparations are usually mixtures of pectin lyase, pectin methylesterase, polygalacturonase, hemicellulase, cellulase and protease. Their role during maceration is breaking down the cellular structure of the grape skin and releasing of anthocyanins and co-pigmentation factors. The efficiency of their use is not consistent (Watson et al., 1999, Delteil, 2000, Canal-Lauberes and Pouns, 2002, Revilly and Gonzales-San Jose, 2002, Bautista-Ortin et al., 2005, Kelebek et al., 2007, Ortega-Heras et al., 2012, Rio Segade et al, 2015). It depends on the conditions of maceration, characteristics of the commercial preparations, impurity and potential contamination with other enzymes, beta-glucosidase or phenol esterases that can have a negative side-effect (van Rensburg and Pretorius, 2000). Babić is a Croatian autochthonous red grape variety with a high potential to produce quality wine, grown on limited top localities. In fertile and deeper soil it can be a highyielding variety with average quality wine (Mirošević and Turković, 2003). Consumption of young red wines is becoming more and more popular. The main attribute of its sensory quality

dr. sc. Ivana Alpeza, Dragica Kaštelanac, mag spec., Hrvatska agencija za poljoprivredu i hranu,

centar za vinogradarstvo, vinarstvo i uljarstvo, Jandrićeva 42, 10000 Zagreb, croatia

prof. dr. sc. Karin Kovačević Ganić, Sveučilište u Zagrebu Prehrambeno biotehnološki fakultet, 10000 Zagreb, Pierottijeva 6, croatia

dr. sc. AndrejaVanzo, Kmetijski inštitut Slovenije, Hacquetova ulica 17, 1000 Ljubljana, Slovenia

Autor za korespondenciju: ivana.alpeza@hapih.hr 
is bright, deep and intensive colour. The aim of this work was to determine whether different commercial enzymatic products have influence on chromatic and sensory parameters of young wines produced under high-yielding conditions. Wines produced with two different macerating enzymes were compared with standard wines produced without exogenous enzymes. Although the commercial enzymes are used in the wine production, there are no results of scientific research of their effect on the quality of young red wines in Croatia.

\section{Materials and methods}

Wine production

Babić grapes originated from the Šibenik viticulture area (subregion of North Dalmatia). Grape harvest was at technological maturity and transported in $15 \mathrm{~kg}$ boxes, $350 \mathrm{~kg}$ in total. The grapes were crushed and destemmed, and wine juice distributed into suitable tanks, with add $15 \mathrm{~g} / \mathrm{kg}$ of potassium metabisulphite. The selected yeast, Saccharomyces cerevisiae, with neutral properties was used with yeast nutrient. The alcoholic fermentation was monitored and kept at $20-22{ }^{\circ} \mathrm{C}$. The fermentation cap was punched down twice a day. At the end of the alcoholic fermentation all wines were pressed and free-run. The wines were stored under controlled condition and racked two times. The potassium metabisulphite was added each time $(10 \mathrm{~g} / \mathrm{hL})$.

\section{Enzymatictreatments}

Treatment T1 (Control): 7- day maceration in the same conditions as well as T2 and T3, but without enzyme addition. Treatment T2: maceration with the addition of a commercial preparation A (Lallemand, France). Its standard composition includes 4000 Pgu/g (polygalacturonase), $1000 \mathrm{Peu} / \mathrm{g}$ (pectin esterase) and $120 \mathrm{Plu} / \mathrm{g}$ (pectin lyase), extracted from Aspergillus niger. The recommended dosage of enzyme is $2 \mathrm{~g} / 100 \mathrm{~kg}$ of grapes, dissolved in water in a 1:10 ratio. Treatment T3: maceration with the addition of a commercial preparation $\mathrm{B}$ (Lallemand, Estonia) with recommended dosage of $30 \mathrm{~g} / 100 \mathrm{~kg}$ of grapes, dissolved in water in a 1:10 ratio. The preparation B comprises pectinases and inactive Saccharomyces cerevisiae yeast cells.

\section{Analysis of chemical parameters}

The wine basic parameters as followed: alcohol, extract, reducing sugar, $\mathrm{pH}$, total and volatile acidity, ash and $\mathrm{SO}_{2}$ were analysed by OIV methods (Compendium of International Methods of Analyses of Wine and Musts).Absorbance (A) measurements were performed at the end of fermentation and in young wines during december, by Perkin Elmer UV/VIS, Lambda 20 spectrophotometer, with $0.2 \mathrm{~cm}$ path length glass cells. Colour intensity $(\mathrm{Cl})$ was calculated as the sum of absorbance at 420, 520 and $620 \mathrm{~nm}$ (Glories, 1984), and tint (CH) as the ratio between absorbance at $420 \mathrm{~nm}$ and absorbance at $520 \mathrm{~nm}$ (OIV-MA-AS2-07B). The percentages of yellow $\left(A_{420} / C l \times 100\right)$, red $\left(A_{520} / C l \times 100\right)$ and blue $\left(A_{620} / C l \times 100\right)$ pigments were calculated as well (Glories, 1984). Specific anthocyanins were extracted and identified by the liquid chromatography (Agilent HPLC 1100), with DAD detector and NDS ChemStation (Agilen Technologies, USA) according to the method reported by Vanzo et al. (2008). The quantity of the following 16 anthocyanins was determined in the wine samples: 3-monoglucosides of delphinidin (Dp3-gl), cyanidin (Cy-3-gl), petunidin (Pt-3-gl), peonidin (Pn-3-gl) and malvidin (Mv-3-gl); acetic acid-acylated 3-monoglucosides of delphinidin (Dp-3-gl-ac), cyanidin (Cy-3-gl-ac), petunidin (Pt-3-gl-ac), peonidin (Pn-3-gl-ac) and malvidin (Mv-3-gl-ac), p-coumaric acid esters of the 3-monoglucosides: 3-monoglucoside p-coumarats of delphinidin (Dp-3-gl-pcum), cyanidin (Cy-3-gl-pcum), petunidin (Pt-3-gl-pcum), peonidin (Pn- 3-gl-pcum) and malvidin (Mv-3-glpcum), and malvidin-3-monoglucoside-caffeoate(Mv-3-gl-caf). 


\section{Sensory Evaluation}

Wines were tested by seven professional wine assessors, oenologists with great knowledge and experience about this grape variety. Two comparative methods were used; Ranking and Paired comparison test (ISO 6658:2005, Stone et al., 2004). Each method was used for the assessment of several characteristics as followed: colour intensity, colour brightness, colour quality and overall quality (overall perception). All technical requirements for conducting sensory analyses were in accordance with ISO/DIS 8589, and the sensory testing procedure is accreditied to HRN EN ISO/IEC 17025.

\section{Data analyses}

The data were submitted to a one-way analysis of variance, to test the effect of pectolytic enzymes. For comparison of mean values, the Duncan's multiple range test was applied. The statistical analyses were performed using Statistica V.7 software (Statsoft Inc., Tulsa, OK).

\section{Results}

The basic quality parameters of Babić wines are presented in Table 1. All data are similar to quality wines of the same vintage, variety and geographical origin, according to the results of official contol in wine certification protocol (https://www.hcphs.hr/croatian-center-for-agriculture-food-and-rural-affairs/).

Table 1. The basic wine quality parameters

Tablica 1. Osnovni parametri kakvoće vina

\begin{tabular}{lcccccc}
\hline & $\mathrm{T} 1 \mathrm{H} 1$ & $\mathrm{~T} 2 \mathrm{H} 1$ & $\mathrm{~T} 3 \mathrm{H} 1$ & $\mathrm{~T} 1 \mathrm{H} 2$ & $\mathrm{~T} 2 \mathrm{H} 2$ & $\mathrm{~T} 3 \mathrm{H} 2$ \\
\hline Alcohol (vol\%) & 11.3 & 11.3 & 11.1 & 11.4 & 11.3 & 11.4 \\
\hline Total dry extract (g/L) & 25.8 & 25.9 & 25.8 & 28.2 & 29.5 & 29.0 \\
\hline Ash (g/L) & 2.5 & 2.4 & 2.4 & 2.4 & 2.5 & 2.5 \\
\hline Reducing sugars (g/L) & 1.3 & 1.6 & 2.1 & 1.6 & 1.9 & 2.1 \\
\hline $\mathrm{pH}$ & 3.4 & 3.4 & 3.4 & 3.4 & 3.4 & 3.3 \\
\hline Totalacidity (g/L,tartraric) & 7.0 & 7.1 & 7.0 & 6.7 & 7.0 & 7.2 \\
\hline Volatile acidity, g/L, acetic) & 0.4 & 0.5 & 0.5 & 0.3 & 0.3 & 0.2 \\
\hline Total SO 2 (mg/L) & 124 & 119 & 131 & 122 & 118 & 115 \\
\hline
\end{tabular}

Legend. T1: control. T2: maceration with product A. T3: maceration with product B. H1: first harvest, $\mathrm{H} 2$ : second harvest.

Kazalo. T1: Kontrola. T2: maceracija s pripravkom A. T3: maceracija s pripravkom B. h1: prva berba. H2: druga berba

\section{Anthocyanins}

Table 2. The concentrations of anthocyanins $(\mathrm{mg} / \mathrm{L})$ in wines

Tablica 2. Koncentracije antocijana ( $\mathrm{mg} / \mathrm{L}) \mathrm{u}$ vinima

\begin{tabular}{|c|c|c|c|c|c|c|}
\hline & $\mathrm{T} 1 \mathrm{H} 1$ & $\mathrm{~T} 2 \mathrm{H} 1$ & $\mathrm{~T} 3 \mathrm{H} 1$ & $\mathrm{~T} 1 \mathrm{H} 2$ & $\mathrm{~T} 2 \mathrm{H} 2$ & $\mathrm{~T} 3 \mathrm{H} 2$ \\
\hline Delphinidin & $21.45^{b}$ & $24.28^{a}$ & $23.89^{a}$ & $15.06^{\mathrm{a}}$ & $17.40^{\mathrm{a}}$ & $16.98^{a}$ \\
\hline Cyanidin & $4.14^{a}$ & $4.45^{a}$ & $4.97^{a}$ & $3.31^{c}$ & $7.89^{a}$ & $5.67^{b}$ \\
\hline Petunidin & $32.29^{b}$ & $35.2^{\mathrm{a}}$ & $33.62^{b}$ & $20.39^{b}$ & $24.74^{\text {a }}$ & $23.04^{a}$ \\
\hline Peonidin & $27.93^{a}$ & $29.29^{a}$ & $29.82^{a}$ & $13.99^{b}$ & $17.11^{\mathrm{a}}$ & $15.12^{a}$ \\
\hline Malvidin & $166.02^{b}$ & $178.0^{a}$ & $166.87^{b}$ & $127.55^{b}$ & $139.35^{\mathrm{a}}$ & $133.42^{\mathrm{a}}$ \\
\hline Total monoglucosides & $204.22^{b}$ & $223.73^{a}$ & $207.88^{b}$ & $149.11^{b}$ & $170.72^{\mathrm{a}}$ & $159.83^{a}$ \\
\hline Total acetates & $12.49^{a}$ & $10.63^{a}$ & $13.11^{a}$ & $7.95^{b}$ & $11.53^{a}$ & $8.51^{b}$ \\
\hline $\begin{array}{l}\text { Total monoglucosides } \\
\text { p-coumarates }\end{array}$ & $32.07^{a}$ & $34.92^{\mathrm{a}}$ & $34.59^{a}$ & $21.06^{\mathrm{a}}$ & $22.03^{a}$ & $23.63^{a}$ \\
\hline Totalanthocyanins & $251.83^{b}$ & $271.88^{a}$ & $259.17^{b}$ & $180.30^{b}$ & $206.49^{a}$ & $194.24^{\mathrm{a}}$ \\
\hline
\end{tabular}


Legend. T1: control. T2: maceration with product A. T3: maceration with product B. H1: first harvest, $\mathrm{H} 2$ : second harvest. The mean values within a single line marked by different letter $(\mathrm{a}, \mathrm{b}$ and $\mathrm{c})$ significantly differ according to the Duncan's test $(p<0.05)$.

Legenda: T1: Kontrola. T2: maceracija s pripravkom A. T3: maceracija s pripravkom B. h1: prva berba. H2: druga berba. Srednje vrijednosti unutar reda označene različitim slovima ( $a, b$ i c) značajno su različite temeljem Duncan testa $(p<0.05)$.

The data, obtained by grouping the 16 individual anthocyanins concentrations are presented in Table 2 . The concentrations of total anthocyanins in young wines were different, depending on the treatment. The highest anthocyanin content was found in wines of T2, in both years of experiment, and the differences were at significant level in both years. The wines of T3 contained higher anthocyanins content compared to control treatment too, but significant different was not obtained in both years (Table 2.). Significant differences in the content of monoglucosides were identified between the control (T1) and pectinase preparation A (T2) in both harvests, and between the control and the sample produced by maceration with a combination of pectinase and inactive yeast cells (T3, preparation B) in one harvest. Significant differences in the content of acetates were observed only in one harvest, between the control and T2 (preparation A). There were no significant differences in p-coumarates content between the treatments. Analysing the correlations between specific anthocyanin forms the following significant differences were observed: a difference referring to the delphinidin content in both treatments, but only in the first harvest, a difference in the cyanidin content in both treatments, but only in the second harvest. A significant difference was observed in the content of petunidin forms in both harvests, where the better results were achieved by T2, in one harvest, and T2 in the other compared to the control. The observed differences in the content of peonidin were significant only in one harvest for both treatments compared to the control. A significant differrences between the control and T2 were observed in both harvest for malvidin compounds, and between the control and T3 in one harvest. In comparison with the pectinase maceration, the maceration with a combination of pectinase and inactive yeast cells was not equably efficient. Although the concentration of total anthocyanins in T3 was absolutely higher compared to the control, there was no equable statistical significance, not even in the extraction of malvidin forms.

\section{ColourParameters}

Both treatments had a positive effect on the colour characteristics of Babic young wine in both harvests. After the fermentation and pressing a significantly higher colour intensity was measured in wines of both treatments compared to the control (Table 3.). Differences were also observed between the treatments; a significantly higher colour intensity was observed in wines produced by maceration with pectolytic enzymes (T2). A significant decrease in the colour intensity was observed in all wines after the first racking. However, it is important to emphasise that the colour intensity in wines of both enzyme treatments was still higher than in the control. There was also a statistically significant difference in colour intensity between all treatments. In the first harvest, the highest colour intensity was observed in T2 treatment, it was significantly higher than the colour intensity of the control and T3 treatment. In the second harvest, the highest colour intensity was achieved in wines which were produced by maceration with a combination of pectolytic enzymes and inactive yeast cells. It was significantly higher than the colour intensity of the control, but did not differ significantly compared to $\mathrm{T} 2$ treatment.

Alterations in the value of the colour hue are followed by the qualitative changes of the wine spectrum. A rise in the value of the colour hue is connected to the colour alterations to- 
ward orange tones, which appear in the wine during the aging process. Still, regardless of the colour intensity values, which were lowest in the control, and the expected inversely proportional values of the colour hue, the results did not confirm this. Contrary to the expectations, after the pressing the colour hue was the lowest (Table 3.) in these wines. A difference was also observed between the different treatments and the lowest colour hue was measured in wines produced by maceration with pectolytic enzymes. An increase of the colour hue value over time was expected and it was observed in all wines. In both treatments, the colour hue was lower in comparison to the control with a statistically significant difference between the control and treatments, and between enzyme treatments too.

The ratio among the specific colours percentages in the wines shown the values very close to optimum; yellow $-35 \%$, red $-55 \%$ and blue $-10 \%$ (Glories, 1984). In the first harvest, all wines had an exceptionally high percentage of the blue colour immediately after pressing. In this phase, the share of both red and yellow colour was equable in all wines, with a slight difference in case of the red colour (Table 3). The percentage of the blue colour significantly drops by aging of the wine. The decrease of a blue colour by more than $5 \%$, and an increase of the red colour, was observed in all young wines. A slight increase of the yellow colour was also observed, but T2 treatment had the best proportion of the yellow (33\%), red (54\%) and blue (13\%). If enzymes are compared, a better colour proportion were observed in wines of product $\mathrm{B}$ (Table 3). These wines maintained the best ratio between the red, blue and yellow colour after the first racking, with red and blue having the higher percentage.

A high linear correlation between anthocyanins and color intensity was obtained in both year of experiment; $R^{2}$ values were 0,988 and 0,913 .

Table 3. Wine colour parameters after fermentation and in young wines

Tablica 3. Parametri boje nakon fermentacije i u mladim vinima

\begin{tabular}{|c|c|c|c|c|c|c|c|c|c|c|c|c|}
\hline & \multicolumn{6}{|c|}{ The end of fermentation } & \multicolumn{6}{|c|}{ Young wines } \\
\hline & $\mathrm{T} 1 \mathrm{H} 1$ & $\mathrm{~T} 2 \mathrm{H} 1$ & $\mathrm{~T} 3 \mathrm{H} 1$ & $\mathrm{~T} 1 \mathrm{H} 2$ & $\mathrm{~T} 2 \mathrm{H} 2$ & $\mathrm{~T} 3 \mathrm{H} 2$ & $\mathrm{~T} 1 \mathrm{H} 1$ & $\mathrm{~T} 2 \mathrm{H} 1$ & $\mathrm{~T} 3 \mathrm{H} 1$ & $\mathrm{~T} 1 \mathrm{H} 2$ & $\mathrm{~T} 2 \mathrm{H} 2$ & $\mathrm{~T} 3 \mathrm{H} 2$ \\
\hline$A_{420}$ & 0.268 & 0.261 & 0.296 & 0.214 & 0.230 & 0.216 & 0.307 & 0.370 & 0.358 & 0.251 & 0.256 & 0.260 \\
\hline$A_{520}$ & 0.455 & 0.439 & 0.508 & 0.330 & 0.381 & 0.348 & 0.494 & 0.559 & 0.555 & 0.359 & 0.399 & 0.410 \\
\hline$A_{620}$ & 0.118 & 0.121 & 0.148 & 0.087 & 0.091 & 0.086 & 0.192 & 0.239 & 0.220 & 0.106 & 0.112 & 0.107 \\
\hline $\begin{array}{l}\mathrm{Cl}\left(\mathrm{A}_{420}+\mathrm{A}_{520}\right. \\
\left.+\mathrm{A}_{620}\right)\end{array}$ & $0.993^{b}$ & $1.168^{\mathrm{a}}$ & $1.133^{\mathrm{a}}$ & $0.716^{\mathrm{a}}$ & $0.776^{a}$ & $0.782^{\mathrm{a}}$ & $0.631^{\mathrm{a}}$ & $0.702^{\mathrm{a}}$ & $0.65^{\mathrm{a}}$ & $0.631^{\mathrm{b}}$ & $0.702^{\mathrm{a}}$ & $0.650^{b}$ \\
\hline $\begin{array}{l}\mathrm{CH}\left(\mathrm{A}_{420} /\right. \\
\left.\mathrm{A}_{520}\right)\end{array}$ & $0.621^{\mathrm{a}}$ & $0.662^{\mathrm{a}}$ & $0.645^{a}$ & $0.702^{\mathrm{a}}$ & $0.666^{a}$ & $0.634^{a}$ & $0.649^{a}$ & $0.605^{a}$ & $0.621^{a}$ & $0.649^{a}$ & $0.605^{a}$ & $0.621^{\mathrm{a}}$ \\
\hline $\begin{array}{l}\% 420 \\
\text { (yellow) }\end{array}$ & $30.9^{\mathrm{b}}$ & $31.9^{\mathrm{a}}$ & $31.6^{\mathrm{a}}$ & $35.1^{\mathrm{a}}$ & $34.2^{\mathrm{b}}$ & $33.3^{c}$ & $33.9^{\mathrm{a}}$ & $32.8^{\mathrm{b}}$ & $33.2^{\mathrm{c}}$ & $33.9^{\mathrm{a}}$ & $32.8^{\mathrm{b}}$ & $33.2^{\mathrm{a}}$ \\
\hline$\% 520$ (red) & $49.8^{a}$ & $47.9^{c}$ & $49.0^{b}$ & $50.1^{c}$ & $51.4^{b}$ & $52.4^{\mathrm{a}}$ & $52.3^{c}$ & $54.3^{\mathrm{a}}$ & $53.5^{b}$ & $53.3^{b}$ & $54.3^{a}$ & $53.5^{b}$ \\
\hline$\% 620$ (blue) & $19.3^{b}$ & $20.5^{a}$ & $19.4^{b}$ & $14.8^{\mathrm{a}}$ & $14.4^{\mathrm{a}}$ & $13.7^{\mathrm{a}}$ & $13.8^{\mathrm{a}}$ & $13.0^{\mathrm{b}}$ & $13.2^{\mathrm{a}}$ & $13.8^{\mathrm{a}}$ & $13.0^{\mathrm{a}}$ & $13.2^{\mathrm{a}}$ \\
\hline
\end{tabular}

Legend: T1: control. T2: maceration with product A. T3: maceration with product B. $\mathrm{H} 1, \mathrm{H} 2$ : harvests. The mean values within a single line marked by different letters $(a, b$ and $c)$ significantly differ according to the Duncan's test $(p<0.05)$.

Legenda: T1: Kontrola. T2: maceracija s pripravkom A. T3: maceracija s pripravkom B. h1: prva berba. H2: druga berba. Srednje vrijednosti unutar reda označene različitim slovima ( $a, b$ i c) značajno su različite temeljem Duncan testa $(p<0.05)$. 


\section{Sensory Evaluation of Wine}

Wines were tested in three repetitions with Ranking method, by 7 assessors considering the organoleptic characteristic, colour intensity, brightness and quality, and overall quality. According to the statistical tables for LSD of 5\%, each sum ("rank total") which falls out of 10 - 18 range is statistically significant. For a $1 \%$ LSD, each sum which falls out of $8-20$ range is statistically significant. Using the Paired comparison test, the wines were presented with the pairs T1-T2 and T2-T3. The assessors evaluated the intensity and quality of colour and overall perception, in three repetitions. In case of this method, according to the appropriate statistical tables for a 5\% LSD, with 7 assessors, all of them need to choose the same sample ((Stone et al., 2004 and Kahan et al.,1973).

According to the results of both methods, fermentation with product $A$ potentiated best colour quality wines. Wines produced by maceration with product B were significantly better compared to the control (Paired comparison test) in the first harvest. The results were partially confirmed in the second harvest; only for the colour intensity and quality, between the control and T2 treatment, despite the fact that the majority of the wine tasters ( 5 out of 7 opted for T1/T3 and T2/T3) chose T2 wines as better. The Ranking method confirmed the results of the Paired comparison test. The wines produced by maceration with products $A$ were significantly better ranked $(P<0.01)$ than the control, for all colour parameters (Figure 1.).

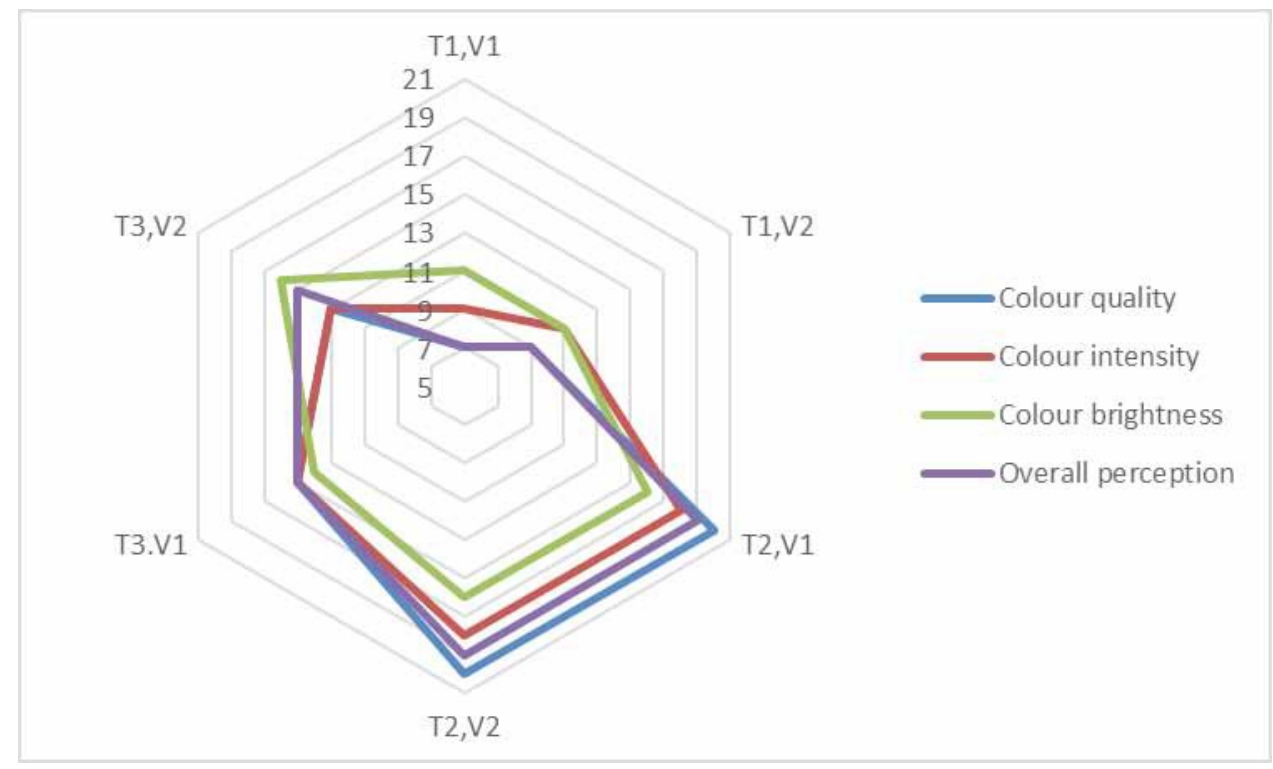

Figure 1. Ranking of the sensory parameters

Legend. T1: control. T2: maceration with product A. T3: maceration with product B. H1: the first harvest, $\mathrm{H} 2$ : the second harvest.

Grafikon 1. Rangiranje senzornih parametara

Legenda: T1: Kontrola. T2: maceracija s pripravkom A. T3: maceracija s pripravkom B. h1: prva berba. H2: druga berba.

The Ranking method was used for the assessment of the general quality too, described as overall perception (Figure 1.). The control wines (T1) ranked lowest in both harvests. A significant difference between those wines and the wines produced by maceration with product $A$ 
(T2) was observed in both years. The significant difference $(P<0.05)$ observed for maceration with combination of enzymes and inactive yeast cells (product $B$, treatment T3) in the first harvest was not confirmed in the second harvest. According to Ranking method results, wines produced by controlled fermentation with product $A$ had the best overall perception of sensory quality.

\section{Discussion}

A comparison of our results referring to the wines of Babic variety with previous results for the same variety is not possible. The results of other researches referring to other varieties and differentiate the effects of exogenous enzymes in a similar manner. Guerrand and Gervais, 2002, Wolz et al., 2004, and Puertolas et al., 2009, tasted the product A and achieved the positive effects on anthocyanins. Furthermore, Watson et al., 1999, and Guadalupe et al., 2007, observed better colour characteristics, depending on the research. Better sensory characteristics of wines produced by using the product A were observed in some research too (Guerrand and Gervais (2002), Guadalupe et al. (2007) and Gambuti et al. (2007). Some other authors achieved the same results of sensory quality with other products (Kelebek et al., 2007, Bucelli et al., 2006). However, the inconsistency or lack of the significant effect of enzymatic preparations to the sensory characteristics of wine is also recorded (Bakker et al., 1999, Bautista - Ortin et al., 2005, Espejo and Armada, 2010). It must be emphasised that the effect of enzymes is best visible right after fermentation. It still persist in young wines, but is less pronounced and significantly reduced. A positive effect of enzymes to different quality parameters was observed by some other outhors, taking the wine variety into consideration, primarily because of an active correlation between the grape skin and flesh (Gonzales-Neves et al., 2001, 2003, Ortega-Heras et al., 2007, Gonzales San Jose et al., 2003, Parley et al., 2001, Gonzales San Jose M.L. et al., 2003, Revilla and Gonzales-Sanjose, 2003a and 2003b, Gambuti et al., 2007 and Kelebek et al., 2007). The enzymes have positive effect on the extraction of anthocyanins, but also on the polymerisation reactions which ensure colour stability. The co-occurrence of anthocyanins and other phenol compounds with co-pigmentation characteristic, as well as a high share of acetaldehyde at the beginning of fermentation can induce the condensation reactions between flavanols and anthocyanins, and thus creation of new coloured forms together with co-pigmentation reactions. The foregoing reactions can affect higher values of the colour intensity and composition of stable anthocyanins. It is nown that differences observed immediately after fermentation are in connection with anthocyanins, monomeric primarily, and reactions such as co-pigmentation, polymerisation and condensation, and all foregoing processes effect the stabilisation of colour (Munoz et al., 2004, Monagas et al., 2005, Ducasse et al., 2010). Some of the above-mentioned authors, with other authors as well emphasise the wine aging as the main factor affecting the reduction or loss of significance of exogenous enzymes (Haight and Gump 1994, Zimman et al., 2002, Clare et al., 2002, Guerrard and Gervais, 2002, Bucelli et.al., 2006, Bajard-Sparrow et al., 2005, Riponi et al., 2005, Saenz-Navajas et al., 2006, Romero-Cascales et al., 2006, Puertolas et al, 2009, Gonzales-Neves, 2012, Rio Segade et al. 2015, Gonzales-Neves et al., 2015). It was evident in both quantitative and qualitative quality parameters; total phenols, anthocyanins, colour intensity and hue, ratio between blue, red and yellow. According to Main and Moriss (2007), the application of product B was not meaningful in case of Cynthiana variety. The Cynthiana variety ( $V$. Aestivalis) comprises a large range of pigments, with the same proportion between malvidin-3-monoglucoside and malvidin-3.5-diglucoside, while $V$. vinifera comprises malvidin-3-glucoside as the main anthocyanin. Malvidin-3.5-diglucoside has an outstanding potential to create co-pigments, much more than malvidin-3-glucoside, and it may be an explanation for the different effect of enzymes. A simple explanation for the lack of 
continuous effects of product $B$ is not simply to elucidate. It is supposed that such results are raleted to a complex composition of product $\mathrm{B}$. Besides the enzymes and their possible secondary activity caused by impurity, the additional activity can relate to inactive yeast cells and its decomposition products (Monagas etal.,2005).

The secondary activities which are the aftermath of enzyme impurities, especially $\beta$ glucosidase, and non-adherence to the recommended doses of application, are the main reasons for the reduction of enzyme influence (Romero-Cascales et al., 2008, Romero-Cascales et al., 2012). Bautista-Ortin et al., 2005, 2007). It suggests a very careful technological approach and mandatory testing of all oenological industrial products in real conditions of production. The grape quality should be the main factor in selection and use of oenological treatment.

\section{Conclusion}

The use of specific pectolytic enzymes can improve polyphenolic and sensory characteristics of young red wines of Babic variety. The recommandation of its use should be based on preliminary research of their efficiency, in particular conditions, referring to the grape variety and quality. Preliminary research in small scale are necesarry and very important therefore. By appropriate enzyme application it is possible to produce young wines with more complexity and easy-drinking at the same time.

\section{References}

Bajard-Sparrow C., Fauveau C., Fernandez O., Samson A. (2005) Maceration enzyme for enhanced colour extraction and stabilization. URL: www.newworldwinemaker.com (1. 2. 2016.)

Bakker J., Bellworthy S.J., Reader H.P., Watkins S.J. (1999) Effect of enzymes during vinification on color and sensory properties of Port wines. American Journal of Enology and Viticulture, 50, 271-276.

Bautista-Ortin A.B., A. Martinez-Cutillas, J.M. Ros-Garcia, J.M. Lopez-Roca Gomez-Plaza E. (2005) Improving colour extraction and stability in red wines: the use of maceration enzymes and enological tannins. International Journal of Food Science and Technology, 40, 867-878.

Bucelli P., Piracci A., Faviere V., Giannetti F., Scotti B., Bergaglio F. (2006) Effect of the application of maceration enzymes on red wine colour stability. The Australian \& New Zealand Grapegrower \& winemaker, 514, 71-75.

Canall-Llauberes R.M., Pouns J.P. (2002) Les enzymes de maceration en vinification en rouge - Influence d'une nouvelle preparation sur la composition des vins. Revue des Oenologues, 29, 29-31.

Clare S.S., Skurray G., Theaud L. (2002) Effect of a pectolytic enzyme on the colour of red wine. The Australian \& New Zealand Grapegrower \& winemaker, January, 29-35.

Ducasse M.A., Canal-LLauberes R.M., Lumley M., Williams P., Souquet J.M., Fulcrand H., Doco T., Cheynier V. (2010) Effect of macerating enzyme treatment on the polyphenol and polysaccharide composition of red wines. Food Chemistry, 118, 369-376. DOI: 10.1016/j.foodchem.2009.04.130

Espejo F., Armada S. (2010) Effect of enzyme addition in the making of Pedro Ximenez sweet wines using dynamic pre-fermentative maceration. South African Journal of Enology \& Viticulture, 31 (2), 133-142

Gambuti A., D. Strollo, A. Erbaggio, I. Lecce, I. Moio (2007) Effect of wine making practices on color indexes and selected bioactive phenolics of Aglianico wine. Journal of Food Science, 72, S623-S628.

Glories Y. (1984) La couleur des vins rouges. 2eme partie: mesure, orige et interpretation. Connaissannce de la Vigne et du Vin, 18, 253-271.

Gonzalez-Neves, G.; Balado, J., Barreiro L., Bochicchio R., Gatto G., Gil G., A. Tessore, M. Ferrer. (2003) Efecto de algunas practicas de manejo del vinedo y de la vinificacion en la composicion fenolica y el color de los vinos tintos. In: Actas $X$ Congresso Brasileiro de Viticultura e Enologia, 43-54.

Gonzalez-Neves, Favre G., Piccardo D., Gil G. (2015) Anthocyanin profile of young red wines of Tannat, Syrah and Merlot made using maceration enzymes and cold soak. International Journal of Food Science \& Technology, 51, 260267

Guadalupe Z., Palacios A., Ayestaran B. (2007) Maceration enzymes and mannoproteins: a possible strategy to increase colloidal stability and color extraction in red wines. Journal of Agriculture and Food Chemistry, 55, 4854-4862.

Guerrand D., Gervais J.P. (2002) Extraction of red wine phenolics during fermentation: a new pectinase preparation. The Australian \& New Zealand Grapegrower \& Winemaker, 60-64.

Haight K.G., Gump B.H. (1994) The use of macerating enzymes in grape juice processing. American Journal of Enology and Viticulture, 45, 113-116.

Kahan G., Cooper, D., Papavasiliou, A., and Kramer, A. (1973) Expanded tables for determining significance of differences for ranked data. Food Technology, 27, 64-69.

Kelebek H., Canbas A., Cabaroglu T., Selli S. (2007) Improvement of anthocyanin content in the cv. Okuzgozu wines by using pectolytic enzymes. Food Chemistry, 105, 334-339.

Main G.L., Morris J.R. (2007) Effect of macerating enzymes and postfermentation grape-seed tannin on the color of Cynthiana wines. American Journal of Enology and Viticulture, 58 (3), 365-372. 
Mirošević N., Turković Z. (2003) Ampelografski atlas. Zagreb. Golden marketing. Tehnička knjiga. ISBN 953-212-019X. $62-63$

Monagas M., Bartolome B., Gomez-Cordoves C. (2005) Updated knowledge about the presence of phenolic compounds in wine. Critical rewiews. Food Science and Nutrition, 45, 85-118. DOI: 10.1080/10408690490911710

Munoz O., Sepulveda M., Schwartz M. (2004) Effects of enzymatic treatment on anthocyanic pigments from grapes skin from Chilean wine. Food Chemistry, 87, 487-490.

Ortega-Heras M., Perez-Magarino S., Gonzales-Huerta C., Herrera P. (2007) Estudio comparativo de la adicion de enzimas de maceracion y de la criomaceracion sobre el color y composicion fenolica de un vino tinto. Proceeding of XXXth OIV World Congress of Vine and Wine. Budapest. Hungary. 10-16 June 2007.

Ortega-Heras M., Perez-Magarino S., Gonzales-Sanjose M.L. (2012) Comparative study of the use of maceration enzymes and cold pre-fermentative maceration on phenolic and anthocyanic composition and colour of a Mencia red wine. LWT-Food Science and Technology, 48 (1) 1-8. DOI: 10.1016/j.Iwt.2012.03.012

Ough C.S., Berg H.W. (1974) The effect of two commercial pectic enzymes on grape musts and wines. American Journal of Enology and Viticulture, 25, 208-211

Parley A., Vanhanen L., Heatherbell D. (2001) Effects of pre-feermentative enzyme maceration on extraction and colour stability in Pinot noir wine. Australian Journal of Grape and Wine Research, 7, 146-152.

Puértolas E., G. Saldaña, S. Condón, I. Álvarez, J. Raso. (2009) Evolution of polyphenolic compounds in red wine from Cabernet Sauvignon grapes processed by pulsed electric fields during aging in bottle. Food Chemistry. 119 (3), 1063-1070.

Revilla I., Gonzales-San Jose M.L. (2003a) Addition of pectolytic enzymes: an enologycal practise which improves the chromacity and stability of red wines. International Journal of Food science and Technology, 38, 29-36.

Revilla I., Gonzales-San Jose M.L. (2003b) Compositional changes during the storage of red wines treated with pectolytic enzymes: low molecular-weight phenols and flavan-3-ol derivative levels. Food Chemistry, 80, $205-214$.

Rio Segade S., Pace C., Torchio F., Giacosa S., Gerbi V., Rolle L. (2015) Impact of maceration enzymes on skin softening and relationship with anthocyanin extraction in wine grapes with different anthocyanin profiles. Food Research International. 71, 50-57. DOI: 10.1016/j.foodres.2015.02.012

Riponi C., Sartini E., Arfelli G., Seghetti L., Di Domenica B., Bucci S. (2005) L'impiegodi enzimi di macerazione nella vinificazione in rosato: il Montepulciano d'Abruzzo Cerasuolo. Vignevini, 6, 73-76.

Romero-Cascales I., Fernandez-Fernandez J.I., Ros-Garcia J.M., Lopez-Roca J.M., Gomez-Plaza E. (2008) Characterisation of the main enzymatic activities present in six commercial macerating enzymes and their effects on extracting colour during winemaking of Monastrell grapes. International Journal of Food Science and Technology, 43, 1295-1305.

Romero-Cascales I., Ros-Garcia J.M., Lopez-Roca J.M., Gomez-Plaza E. (2012) The effect of a commercial pectolytic enzyme on grape skin cell wall degradation and colour evolution during the maceration process. Food Chemistry. 130 (3), 626-631.

Rosario-Salinas M., Garijo J., Pardo F., Zalacain A., Alonso G.L. (2003) Color, polyphenol and aroma compounds in rose wines after prefermentative maceration and enzymatic treatments. American Journal of Enology and Viticulture, 54, 195-202.

Saenz-Navajas M.P., Guadalupe Z., Tena M.T. (2006) Use of maceration enzymes and mannoproteins in red wine during winemaking. Influence on wine pigments. Proceeding of XXIXth OIV Congress, Logrono, Spain. 25-30 June 2006.

Stone H., Bleibaum R.N., Thomas H.A. (2004) Sensory evaluation practices. Third edition. Elsevier. USA

du Toit W.J., Visagie M. (2012) Correlations between South African Red Grape and Wine colour and phenolic composition: comparing the Glories, Iland and Bovine Serum albumin tannin precipitation methods. South African Journal of Enology and Viticulture, 33, 33-41.

Van Resburg P., Pretorius I.S. (2000) Enzymes in winemaking: Harnessing natural catalyst for efficient biotransformations - a Review. South African Journal of Enology and Viticulture, Special Issue. 21, 52-73.

Vanzo A., Terdoslavich M., Brandoni A., Torres A.M., Vrhovšek U. (2008) Uptake of grape anthocyanins into the rat kidney and the involvement of bilitranslocase. Molecular Nutrition \& Food Research. 52, 1106-1116.

Watson B., Goldberg N., Chen H.P., Mc Daniel M., Price S. (1999) Effects of macerating pectinase enzymes on color, phenolic profile and sensory character of Pinot noir wines. Proceeding of the second Joint Burgundy-California-Oregon Winemaking Symposium. USA. 8-9 February 1999. UC Davis. 36-44.

Wolz S., Schormann A., Putzer K., Guerrand D., Fisher U. (2004) Color Extraction and stability in Pinot noir wines from cool climate: impact of a new pectinaze preparation. 7th International Symposium on Innovations in Enology. Postersection, 9-11 May 2004., Stuttgart, Germany: Intervitis Interfructa.

Zimman A., Joslin W., Lyon M, Meier J., Waterhouse A. (2002) Maceration variables affecting phenolic composition in commercial-scale Cabernet sauvignon winemaking trials. American Journal of Enology and Viticulture, 53, 93-98.

Prispjelo/Received: 20.5.2020. 


\section{Učinak primjene komercijalnih pektolitičkih enzima na kakvoću mladog vina Babić}

\section{Sažetak}

Svrha ovog istraživanja bila je ispitati utjecaj komercijalnih pripravaka pektolitičkih enzima na sastav antocijana, parametre boje i određene senzorne atribute u mladim vinima autohtone sorte Babić. Tijekom dvije berbe, maceracija bez komercijalnih enzima uspoređivana je s dva tretmana s različitim enzimatskim pripravcima; pektinaza sa sekundarnom aktivnošću celulaza u hemicelulaza (A) te pektinaza s inaktivnim stanicama kvasaca (B). Oba proizvoda utjecala su pozitivno na sadržaj i sastav antocijana, ali s različitim intenzitetom. Pozitivan utjecaj enzimaočitovanjeikrozparametreboje; intenzitet, nijansuirelativanodnos između žute, crvene i plave boje, ali ovisno o sastavu pripravka. Svi mjereni parametri kakvoće mladih vina proizvedeni maceracijom s pripravkom A bili su bolji u odnosu na kontrolan tretman i djelomično bolji u odnosu na tretman s pripravkom B. Senzorne analize potvrdile su rezultate kemijskih parametara i mlada vina maceracije s pektolitičkim enzimima bila su senzorno značajno bolja. Pripravak kombinacije enzima $i$ inaktivnih stanica kvasaca (B) nije imao ujednačen učinak tijekom dvije berbe, bez obzira na parametar kakvoće. Temeljeno na rezultatima ovog istraživanja, primjena komercijalnih pektolitičkih enzima može biti korisna kao tehnološki postupak osiguranja primarnih čimbenika kakvoće mladih vina sorte Babić. Međutim, ovi rezultati upućuju također i na potrebu istraživanja prije primjene u stvarnoj proizvodnji, radi selekcije i preporuke specifičnih enzimatskih pripravaka, vodeći računa o sorti i svojstvima kakvoće koje je potrebno poboljšati.

Ključne riječi: antocijani, boja, senzorna kakvoća, pektolitički enzimi, vino, Babić

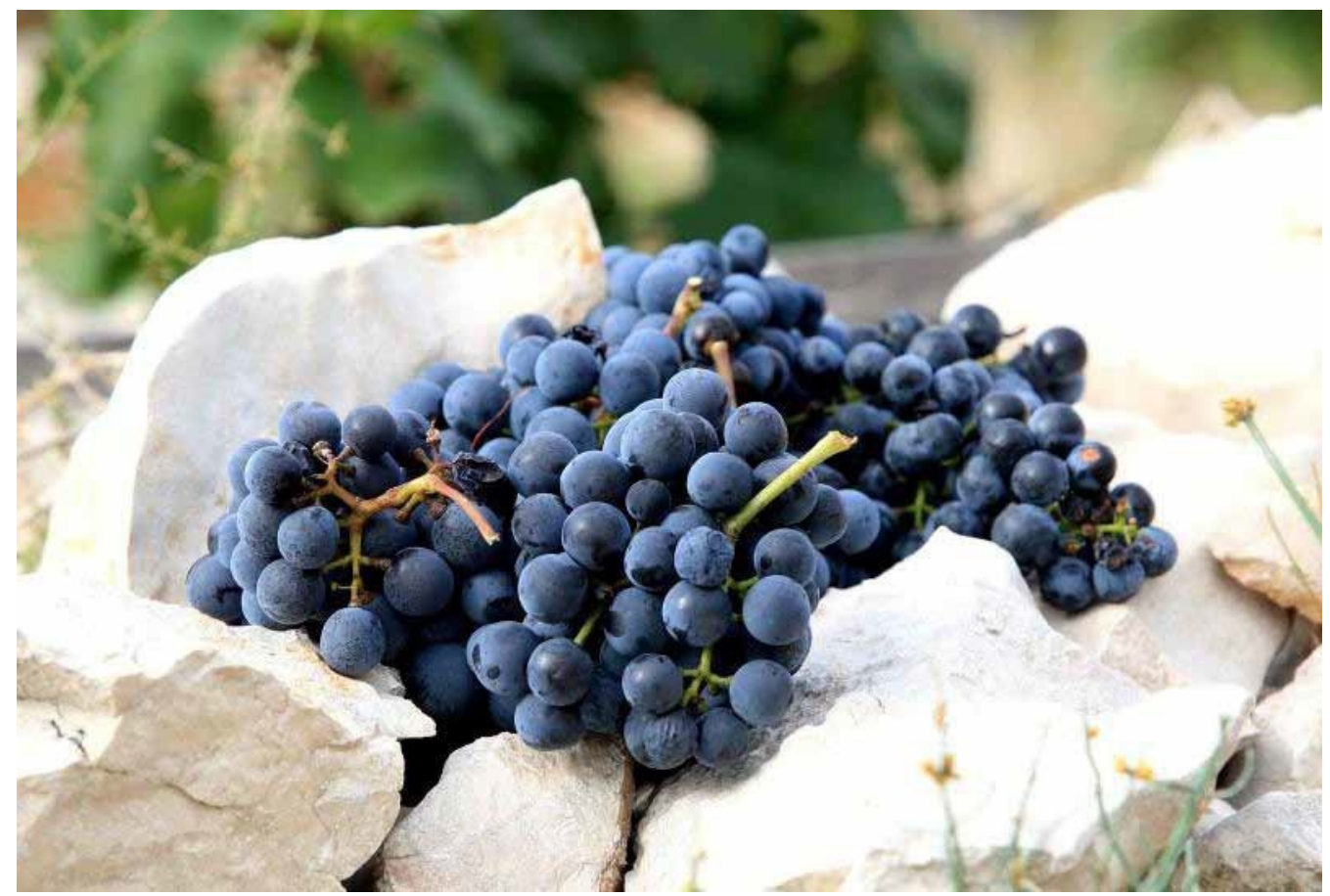

